\title{
Evaluation of Oxidative Stress in Type 2 Diabetes Mellitus Patients
}

\author{
Dr. M.Kusuma Kumari, $\mathrm{MD}^{1}$; Dr.T.Sankaranarayana, $\mathrm{MD}^{2}$ \\ I'Senior Resident, Dept. of Biochemistry, S.V. Medical College, Tirupati, Andhra Pradesh, India) \\ ${ }^{2}$ (Asst. Professor, Dept. of Biochemistry, Siddhartha Medical College, Vijayawada, Andhra Pradesh, India)
}

\begin{abstract}
:
Introduction: Poorly controlled blood glucose levels accelerate hyperglycaemia-induced excess free-radical generation, dyslipidemia and thereby causing OS induced cellular inflammation, damaging blood vessels in type2diabetics. Aim \& Objectives: To evaluate OS in T2DM, by estimating malondialdehyde (index of lipid peroxidation), uricacid \& ceruloplasmin (physiological, endogenous free-radical scavengers), and correlating them with $\mathrm{HbA}_{I C}$ and lipid profile. Methodology: The study included 50 Type2diabetics and 50 age and sex matched controls (36-60yrs). Fasting \& post-prandial glucose, $H b A_{I C}$, lipid profile, malondialdehyde, uricacid and ceruloplasmin were estimated using standard methods. Results: In Type2diabetics increased Triglycerides, Total-cholesterol, VLDL, LDL, MDA, UA \& CP and decreased HDL values were observed. MDA,CP,UA,LDL showed significant positive correlation with $H b A_{1 c}$ while $H D L$ showed significant negative correlation with $H b A_{I C}$. MDA, CP, UA showed significant positive correlation with $L D L$ and significant negative correlation with HDL. MDA,CP,UA showed significant positive correlation with one another. Conclusions: It is of utmost importance to achieve tight control of blood glucose $\left(H_{b A_{I C}}<6.5 \%\right), L D L(<100 \mathrm{mg} / \mathrm{dL})$ and $H D L(>40 \mathrm{mg} / \mathrm{dL})$, earlier in the disease to reduce OS in T2DM.
\end{abstract}

Keywords: Oxidative stress(OS), Malondialdehyde (MDA), Uric acid (UA), Ceruloplasmin (CP), Type 2 diabetes mellitus(T2DM).

\section{Introduction}

Oxidative stress, through the production of reactive oxygen species (ROS), has been proposed to be the unifying link between the various molecular disorders underlying the development of insulin resistance, $\beta$-cell dysfunction and impaired glucose tolerance leading to the development of type 2 diabetes mellitus [1], [2]. Oxidative stress, secondary to persistent hyperglycaemia and dyslipidemia plays a key role in the pathogenesis of T2DM and its complications by excess ROS generation, auto-oxidation of glucose, non enzymatic protein glycosylation, lipid peroxides formation, impaired glutathione metabolism, impaired activities of antioxidant defence enzymes and decreased concentrations of low molecular weight antioxidants such as ceruloplasmin [3] and uric acid [4].

Malondialdehyde, as TBARS (ThioBarbituric Acid Reacting Substances), is frequently used to determine the prooxidant/antioxidant balance in type 2 diabetic patients as they are stable and easily measurable lipid peroxidation products. Ceruloplasmin acting as ferroxidase decreases the availability of the iron in free radical generating reactions [5]. Considering the pro-oxidant status of patients with T2DM, an increase in the level of CP probably favours its protective action against free radical injury [6]. Alternatively, an increase in serum CP in type 2 diabetes could generate excess oxidized LDL, which causes atherosclerosis [7]. It could also cause vascular injury by generating free radicals, such as hydrogen peroxide, in the course of oxidization of serum homocysteine [8].

Uric acid is the main plasma antioxidant in humans, followed by vitamin C. Uric acid stabilizes vitamin $\mathrm{C}$ in plasma and protects it from oxidation. Urate, the soluble form of uric acid in the blood, can scavenge superoxide radicals, hydroxyl radicals, and singlet oxygen and can chelate transition metals [9]. Uric acid can also block the reaction of superoxide anion with nitric oxide forming peroxynitrite which is a particularly toxic product that can injure cells by nitrosylating the tyrosine residues of proteins[10]

\section{Materials \& Methods}

This study was conducted in the department of biochemistry, Siddhartha medical college, Vijayawada and diabetic clinic in the department of medicine, Government general hospital, Vijayawada.

2.1 Consent: This study was approved by the Institutional Ethics Committee. Informed oral consent was obtained from each participant, after explaining the purpose of this study in their own language, before obtaining the blood sample. 
2.2 Study group: This study included 50 Type 2 diabetic patients without complications as cases and 50 age and sex matched apparently healthy individuals as controls.Complete history was obtained from all the participants and a thorough physical examination was done.

2.3 Inclusion criteria: Patient diagnosed by history, clinical examination and laboratory investigations to have Type 2 diabetes mellitus without any complications falling in the age group of 36 - 60 years were included in the study. Apparently healthy people who are age and sex matched with the sample group are used as controls for the study.

2.4 Exclusion criteria: Patients with macro-vascular complications such as cardiovascular, cerebrovascular and peripheral vascular diseases and micro-vascular complications such as neuropathy, nephropathy and retinopathy were excluded. Patients with hemoglobinopathies, anemia,chronic alcoholism, renal, hepatic and thyroid disorders, febrile illness, diabetic ketoacidosis, renal failure, and those who were suffering from chronic diseases were also excluded from the study. Patients with Type I diabetes mellitus and Type II diabetes mellitus on Insulin therapy were excluded. Patients on lipid modifying drugs like statins or fibrates, steroids, beta blockers, thiazides, phenytoin, etc and pregnant females were excluded.

2.5 Sample collection: Fasting blood samples were taken after an overnight fasting of $12 \mathrm{hrs}$ from all subjects. Under aseptic precautions, $8 \mathrm{ml}$ of blood was drawn from the median cubital vein of the study subjects in two vials, one plain and the other containing anticoagulant mixture of Potassium oxalate and sodium fluoride in the ratio of 2:1. Parameters were analysed from whole blood, plasma and serum. Whole blood is used for estimation of Malondialdehyde by Thiobarbituric acid method [11] and HbA1C by Ion exchange resin method [12]. Plasma is used for fasting glucose estimation by GOD-POD method [13]. Serum for estimation of Cholesterol by CHOD-POD method [14], Triglycerides by GPO method [15], HDL-C by Phosphotungstic acid method [16], Ceruloplasmin by Ravin's method [17], Uric acid by TBHB-POD method [18]. VLDL-C \& LDLC were calculated by Friedwald's formula [19]. Then $2 \mathrm{ml}$ of post prandial blood sample is collected for estimation of post prandial plasma glucose concentration.

2.6 Statistical analysis: Results were analyzed by descriptive statistical analysis using Excel and Medcal statistical software. Results were expressed in terms of Mean \pm standard deviation for each variable. Comparisons of the parameters among groups were done using Analysis of variance (ANOVA) and P $<0.001$ is considered is significant. Pearson's correlation is used to correlate between the variables and with the disease.

\section{Results}

In this study, 100 subjects were studied in which 50 were type 2 diabetic cases and 50 were apparently healthy controls. Both the groups were age and sex matched with 25 males and 25 females in each group. The mean age of the subjects involved in this study was 48.000 \pm 7.2843 . The mean fasting plasma sugar level was higher in cases $(152.860 \pm 23.8019)$ than controls $(87.080 \pm 15.6868)$. The mean postprandial plasma sugar level was higher in cases $(219.14 \pm 46.9055)$ than in controls $(129.860 \pm 5.1824)$. The mean $\mathrm{HbA}_{1 \mathrm{C}}$ value of controls was $5.842 \pm 0.2853$ and that of cases was $8.183 \pm 0.9681$. The mean total cholesterol level of controls was $162.940 \pm 37.4321$ and that of cases was $240.940 \pm 31.9128$. The mean triglyceride level in controls was $127.080 \pm 44.2483$ and that in cases was 208.120 \pm 40.0778 . The mean HDL-C level in controls was $38.500 \pm 4.0520$ and that of cases was $32.500 \pm 3.2655$ which is statistically significant. The mean VLDL-C level in controls was $25.380 \pm 8.9257$ and that of cases was $41.660 \pm 8.0600$. The mean LDL-C level in controls was $99.360 \pm 34.4992$ and that in cases was $167.420 \pm 29.2212$. The mean MDA level in controls was $2.308 \pm 0.6076$ and that in cases was $4.5388 \pm 0.7892$. The mean serum ceruloplasmin level in controls was $45.500 \pm 8.1146$ and that in cases was 70.200 \pm 8.4708 . The mean serum uric acid level in controls was $3.536 \pm 0.3827$ and that in cases was $4.426 \pm 0.5348$. The mean value of all the above parameters except HDL-C was higher in cases than in controls and the difference is statistically significant $(\mathrm{P}<0.001)$ as shown in Table: 1 . The correlation of other parameters with Malondialdehyde was summarised in Table: 2, with Ceruloplasmin in Table: 3, and with Uric acid in Table: 4.

Table 1: Comparison of parameters

\begin{tabular}{|c|l|c|c|c|}
\hline S.No & \multicolumn{1}{|c|}{ Parameter (Mean \pm S.D) } & Controls $(\mathrm{n}=50)$ & Cases $(\mathrm{n}=50)$ & Statistical significance \\
\hline 1. & Fasting plasma sugar & $87.080 \pm 15.6868$ & $152.860 \pm 23.8019$ & F-ratio:266.243(P<0.001) \\
\hline 2. & Postprandial plasma sugar & $129.860 \pm 5.1824$ & $219.140 \pm 46.9055$ & F-ratio:178.962(P<0.001) \\
\hline 3. & HbA $_{1 \mathrm{c}}$ & $5.842 \pm 0.2853$ & $8.183 \pm 0.9681$ & F-ratio:269.034(P<0.001) \\
\hline 4. & Serum total cholesterol & $162.940 \pm 37.4321$ & $240.940 \pm 31.9128$ & F-ratio:125.724(P<0.001) \\
\hline 5. & Serum triglycerides & $127.080 \pm 44.2483$ & $208.120 \pm 40.0778$ & F-ratio:92.133(P<0.001) \\
\hline
\end{tabular}


Evaluation of Oxidative Stress in Type 2 Diabetes Mellitus Patients

\begin{tabular}{|c|l|c|c|c|}
\hline 6. & High density lipoprotein & $38.500 \pm 4.0520$ & $32.500 \pm 3.2655$ & F-ratio:66.466(P<0.001) \\
\hline 7. & Very low density lipoprotein & $25.380 \pm 8.9257$ & $41.660 \pm 8.0600$ & F-ratio:91.625(P<0.001) \\
\hline 8. & Low density lipoprotein & $99.360 \pm 34.4992$ & $167.420 \pm 29.2212$ & F-ratio:113.307( $<0.001)$ \\
\hline 9. & Malondialdehyde & $2.308 \pm 0.6076$ & $4.5388 \pm 0.7892$ & F-ratio:334.111(P<0.001) \\
\hline 10. & Ceruloplasmin & $45.500 \pm 8.1146$ & $70.200 \pm 8.4708$ & F-ratio:302.590(P<0.001) \\
\hline 11. & Uric acid & $3.536 \pm 0.3827$ & $4.426 \pm 0.5348$ & F-ratio:107.060(P<0.001) \\
\hline
\end{tabular}

Table 2: Correlation with Malondialdehyde

\begin{tabular}{|l|c|c|c|}
\hline Parameter & Number of study subjects & $\begin{array}{c}\text { Pearson correlation } \\
\text { coefficient }(\mathrm{r} \text { value })\end{array}$ & Statistical significance \\
\hline Fasting glucose & 100 & 0.847 & $\mathrm{P}<0.0001$ \\
\hline Postprandial glucose & 100 & 0.829 & $\mathrm{P}<0.0001$ \\
\hline $\mathrm{HbA}_{\mathrm{lc}}$ & 100 & 0.866 & $\mathrm{P}<0.0001$ \\
\hline Total cholesterol & 100 & 0.858 & $\mathrm{P}<0.0001$ \\
\hline Triglycerides & 100 & 0.742 & $\mathrm{P}<0.0001$ \\
\hline $\mathrm{HDL}$ & 100 & -0.652 & $\mathrm{P}<0.0001$ \\
\hline VLDL & 100 & 0.740 & $\mathrm{P}<0.0001$ \\
\hline LDL & 100 & 0.847 & $\mathrm{P}<0.0001$ \\
\hline Ceruloplasmin & 100 & 0.913 & $\mathrm{P}<0.0001$ \\
\hline Uric acid & 100 & 0.782 & $\mathrm{P}<0.0001$ \\
\hline
\end{tabular}

Table 3: Correlation with Ceruloplasmin

\begin{tabular}{|l|c|c|c|}
\hline Parameter & $\begin{array}{c}\text { Number of study } \\
\text { subjects }\end{array}$ & $\begin{array}{c}\text { Pearson correlation coefficient } \\
\text { (r value })\end{array}$ & Statistical significance \\
\hline Fasting glucose & 100 & 0.766 & $\mathrm{P}<0.0001$ \\
\hline Postprandial glucose & 100 & 0.800 & $\mathrm{P}<0.0001$ \\
\hline HbA $_{1 \mathrm{c}}$ & 100 & 0.814 & $\mathrm{P}<0.0001$ \\
\hline Total cholesterol & 100 & 0.848 & $\mathrm{P}<0.0001$ \\
\hline Triglycerides & 100 & 0.708 & $\mathrm{P}<0.0001$ \\
\hline HDL & 100 & -0.637 & $\mathrm{P}<0.0001$ \\
\hline VLDL & 100 & 0.708 & $\mathrm{P}<0.0001$ \\
\hline LDL & 100 & 0.840 & $\mathrm{P}<0.0001$ \\
\hline Malondialdehyde & 100 & 0.913 & $\mathrm{P}<0.0001$ \\
\hline Uric acid & 100 & 0.787 & $\mathrm{P}<0.0001$ \\
\hline
\end{tabular}

Table 4: Correlation with Uric acid

\begin{tabular}{|l|c|c|c|}
\hline Parameter & $\begin{array}{c}\text { Number of study } \\
\text { subjects }\end{array}$ & $\begin{array}{c}\text { Pearson correlation coefficient } \\
\text { (r value })\end{array}$ & Statistical significance \\
\hline Fasting glucose & 100 & 0.700 & $\mathrm{P}<0.0001$ \\
\hline Postprandial glucose & 100 & 0.714 & $\mathrm{P}<0.0001$ \\
\hline $\mathrm{HbA}_{\mathrm{c}}$ & 100 & 0.730 & $\mathrm{P}<0.0001$ \\
\hline Total cholesterol & 100 & 0.712 & $\mathrm{P}<0.0001$ \\
\hline Triglycerides & 100 & 0.697 & $\mathrm{P}<0.0001$ \\
\hline HDL & 100 & -0.582 & $\mathrm{P}<0.0001$ \\
\hline VLDL & 100 & 0.698 & $\mathrm{P}<0.0001$ \\
\hline LDL & 100 & 0.689 & $\mathrm{P}<0.0001$ \\
\hline Malondialdehyde & 100 & 0.782 & $\mathrm{P}<0.0001$ \\
\hline Ceruloplasmin & 100 & 0.787 & $\mathrm{P}<0.0001$ \\
\hline
\end{tabular}

\section{Discussion}

Diabetes mellitus is a chronic disease characterized chronic elevations of glucose, nonesterified fatty acids, and oxidative stress. High values of Malondialdehyde, Ceruloplasmin and Uric acid indicate elevated OS in type 2 diabetics. In this study the lipid peroxidation product, MDA measured as TBARS is significantly 
increased in type 2 diabetics than in controls. This finding is in accordance with findings of other studies as illustrated in Table: 5 [20], [21], [22], [23], [24], [25], [26], [27], [28].

TABLE 5: Comparison of present study with other studies in relation to MDA

\begin{tabular}{|l|l|l|l|}
\hline Studies & $\begin{array}{l}\text { Controls } \\
\text { Mean } \pm \text { S.D }\end{array}$ & $\begin{array}{l}\text { Cases } \\
\text { Mean } \pm \text { S.D }\end{array}$ & $\begin{array}{l}\text { Statistical } \\
\text { significance* }\end{array}$ \\
\hline Present study & $2.308 \pm 0.6076$ & $4.5388 \pm 0.7892$ & $\mathrm{P}<0.001$ \\
\hline Jamunarani a. et al., 2012 & 2.62 & 4.36 & $\mathrm{P}<0.001$ \\
\hline Padalkar et al., 2012 & $6.13 \pm 2.3$ & $13.29 \pm 0.72$ & $\mathrm{P}<0.001$ \\
\hline Vivian samuel T, 2011 & $3.62 \pm 0.24$ & $5.14 \pm 0.68$ & $\mathrm{P}<0.001$ \\
\hline Kedari G S R, 2011 & $2.41 \pm 0.12$ & $6.98 \pm 0.13$ & $\mathrm{P}<0.001$ \\
\hline Sarita N. Shinde et al., 2011 & $3.59 \pm 0.97$ & $7.19 \pm 0.64$ & $\mathrm{P}<0.001$ \\
\hline NatheerH al-rawi, 2011 & $1.1 \pm 0.35$ & $2.38 \pm 0.97$ & $\mathrm{P}<0.001$ \\
\hline M. Salem et al., 2011 & $5.81 \pm 2.39$ & $11.13 \pm 3.13$ & $\mathrm{P}<0.001$ \\
\hline Nakhjavani M et al., 2010 & $2.91 \pm 0.59$ & $3.82 \pm 0.93$ & $\mathrm{P}<0.001$ \\
\hline S. A.moussa, 2008 & $1.3 \pm 0.3$ & $3.0 \pm 0.7$ & $\mathrm{P}<0.001$ \\
\hline
\end{tabular}

$* \mathrm{P}<0.001$ is significant

The present study showed significantly increased ceruloplasmin levels in cases when compared to controls. These findings are in accordance with other studies conducted by A. Sarkar et al., 2010 [29], and B.Vîrgolici et al,2008 [30]. The present study showed significantly increased levels of serum Uric acid in type 2 diabetic patients when compared to controls. These findings are in accordance with other studies conducted by Natheer H Al-Rawi, 2011; A. Sarkar et al., 2010 and B.Vîrgolici et al., 2008. The present study showed significant positive correlation of MDA, Ceruloplasmin and Uric acid with $\operatorname{HbA}_{1 \mathrm{C}}(\mathrm{P}<0.0001)$. The present study showed significant positive correlation of MDA with cholesterol, triglycerides, VLDL and LDL (P < $0.0001)$, and significant negative correlation with HDL $(\mathrm{P}<0.0001)$. The present study showed significant positive correlation of Ceruloplasmin with dyslipidemia $(\mathrm{P}<0.0001$.). Similar findings are seen in the studies conducted by B.Vîrgolici et al., 2008 and Sarkar et al., 2010. The present study showed significant positive correlation of Uric acid with cholesterol, triglycerides, VLDL and LDL(P < 0.0001). HDL showed highly significant negative correlation with Uric Acid $(\mathrm{P}<0.0001)$. Similar findings are seen in the studies conducted by B.Vîrgolici et al., 2008 and Natheer H Al-Rawi, 2011.

\section{Conclusion}

Type 2 diabetes is a chronic progressive disease, characterised by hyperglycaemia and dyslipidemia, causing an increased susceptibility of cells to lipid peroxidation and inflammation due to oxidative stress which plays a major role in the pathogenesis of diabetes and its complications. The results of this study and previous works provide ample evidence that poor metabolic control and dyslipidemia in patients with type 2 diabetes mellitus were associated with increased MDA, CP and UA. These observations suggest that supportive therapy aimed at oxidative stress may help prevent the development of complications in type 2 diabetes mellitus. Approaches such as regular physical exercise and/or antioxidant therapy, concurrent with standard treatment, may improve the quality of life and reduce disease progression in type 2 diabetic patients.

\section{References}

[1]. Ceriello A, Motz E. Is oxidative stress the pathogenic mechanism underlying insulin resistance, diabetes, and cardiovascular disease? The common soil hypothesis revisited. ArteriosclerThrombVascBiol 2004; 24: 816-23.

[2]. Santini SA, Marra G, Giardina B, Cotroneo P, Mordente A, Giuseppe E, et al, Defective plasma antioxidant defenses and enhanced susceptibility to lipid peroxidation in uncomplicated IDDM. Diabetes, 46:1853-1858, (1997).

[3]. Goldstein IM, Kaplan HB, Edelson HS, Weissmann G: Ceruloplasmin, a scavenger of superoxide anion radicals. J BiolChem254:4040-4045, 1979

[4]. Ames B.N., Cathcart R., Schwiers E., Hochstein P. Uric acid provides an antioxidant defense in humans against oxidant and radicalcaused aging and cancer: a hypothesis. Proc. Natl. Acad. Sci. USA 1981; 78 (11): 6858- 6862.

[5]. Gutteridge JMC. Ceruloplasmin: a plasma protein, enzyme, and antioxidant. Ann ClinBiochem. 1978; 15:293 - 294.

[6]. Memisogpullari R, Bakan E. Levels of ceruloplasmin, transferrin and lipid peroxidation in the serum of patients with type 2 diabetes mellitus. J Diab Comp. 2004; 18: 193 - 197. 
[7]. Ehrenwald E, Chisolom GM, Foz PL: Intact human ceruloplasmin oxidativelymodifieslow density lipoprotein. J Clin Invest 93:1493-1501, 199

[8]. Starkebaum G, Harlan JM: Endothelial cell injury due to copper-catalyzed hydrogen peroxide generation from homocysteine. J Clin Invest 71:1370-1376, 1986

[9]. Simie MG, Jovanovich SV. Antioxidation mechanisms of uric acid. J Am Chem Soc 1989;111:5778-82.

[10]. Squadrito GL, Cueto R, Splenser AE, Valavanidis A, Zhang H, Uppu RM, et al. Reaction of uric acid with peroxynitrite and implications for the mechanism of neuroprotection by uric acid. Arch BiochemBiophys 2000;376:333-37.

[11]. Placer ZA, Lind L, Cushmann M, Johnson BC. Estimation of product of lipid peroxidation (MDA) in biological systems. Anal Biochem. 1966;16:359-64.

[12]. Trivelli, L.A., Ranney, H.M. and Lai, H.T., Estimation of glycosylated haemoglobin; New Eng. J. Med. 284,353 (1971).

[13]. Tietz, N.W. Fundamentals of clinical chemistry; W.B.Saunders\&Philidelphia PA, 1976; 243.

[14]. Roeschlau P., Bernt E, and Gruber W.A., Estimation of serum cholesterol; clinbiochem 12(226), 1974.

[15]. Fossati P, Prencipe L. Serum triglycerides determined colonmetrically with an enzyme that produces hydrogen peroxide. ClinChem 1982;28:2077-80.

[16]. Burstein M., Scholnick H.R., Morfin R. (1970): Rapid method for isolation of lipoproteins from human serum by precipitation with polyanions. Journal of Lipid Research, 11, 583- 595.

[17]. Ravin HA. An improved colorimetric enzymatic assay of ceruloplasmin. J Lab Clin Med. 1961; 58: $161-168$

[18]. Trivedi R, Rebar L, Berta E, Stong L. New enzymatic method for serum uric acid at 500 nm. ClinChem 1978;24:1908-11.

[19]. Friedewald WT, Levy RI, Fredrickson DS. Estimation of the concentration of low-density lipoprotein cholesterol in plasma, without use of the preparative ultracentrifuge. ClinChem 1972;18:499-502.

[20]. A.JamunaRani, SV.Mythili and ShunmugamNagarajan. Serum nitrite levels in relation to malondialdehyde in type 2 diabetes mellitus: Recent Research in Science and Technology 2012, 4(6): 11-12

[21]. Ramchandra K Padalkar, Ashok V Shinde, Sangita M Patil. Lipid profile, serum malondialdehyde, superoxide dismutase in chronic kidney diseases and Type 2 diabetes mellitus; Biomedical Research 2012; 23 (2): 207-210.

[22]. Vivian Samuel T. Proxidant and antioxidant status in type 2 diabetes with relation to its duration; International Journal of Pharma and Bio Sciences; Vol 2/ Issue 2/ Apr-Jun 2011.

[23]. Kedari G S R Evaluation of the Thyriod Status, OxidantStress and Antioxidant Status in patients with Type - 2 Diabetes Mellitus; Journal of Clinical and Diagnostic Research. 2011 Apr, Vol-5(2):254-256

[24]. Sarita N. Shinde, Vithal N. Dhadke, Adinath N. Suryakar. Evaluation of Oxidative Stress in Type 2 Diabetes Mellitus and Followup Along with Vitamin E Supplementation; Ind J ClinBiochem (Jan-Mar 2011) 26(1):74-77.

[25]. Natheer H Al-Rawi.Oxidative stress, antioxidant status and lipid profile in the saliva of type 2 diabetics; Diabetes \& Vascular Disease Research 8(1) 22-28, 2011

[26]. M. Salem, S. Kholoussi, N. Kholoussi, R. Fawzy. Malondialdehyde and trace element levels in patients with type 2 diabetes mellitus; Archives Of Hellenic Medicine 2011, 28(1):83-88.

[27]. Nakhjavani M, Esteghamati A, Nowroozi S, Asgarani F, Rashidi A, Khalilzadeh O. Type 2 diabetes mellitus duration: an independent predictor of serum malondialdehyde levels; Singapore Med J 2010; 51(7) : 582

[28]. S.A. moussa. Oxidative stress in diabetes mellitus; romanian j. Biophys., vol. 18, no. 3, p. 225-236, bucharest, 2008

[29]. A Sarkar, S Dash, B K Barik, M S Muttigi, V Kedage, J K Shetty and M Prakash. Copper and ceruloplasmin levels in relation to total thiols and gst in type 2 diabetes mellitus patients; Indian Journal of Clinical Biochemistry, 2010 / 25 (1) 74-76

[30]. BogdanaVîrgolici, Maria Mohora, Laura Găman, Daniela Lixandru, B. Manolescu, AncaComan, Irina Stoian. Relation between inflammation and oxidative stress markers in diabetic foot patients; ROMANIAN J. BIOPHYS., Vol. 18, No. 4, P. 273-282, BUCHAREST, 2008. 